This article was downloaded by: [EBSCOHost EJS Content Distribution]

On: 29 July 2009

Access details: Access Details: [subscription number 911724993]

Publisher Routledge

Informa Ltd Registered in England and Wales Registered Number: 1072954 Registered office: Mortimer House, 37-41 Mortimer Street, London W1T 3JH, UK

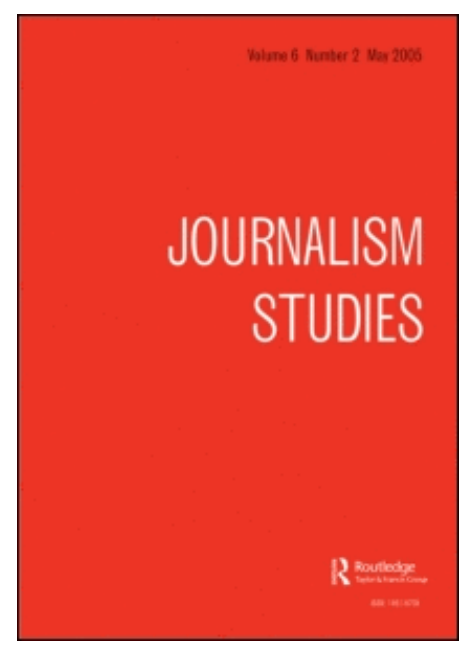

\title{
Journalism Studies
}

Publication details, including instructions for authors and subscription information:

http://www.informaworld.com/smpp/title content=t713393939

\section{Film Portrayals of Foreign Correspondents}

Raluca Cozma a; John Maxwell Hamilton a

a Manship School of Mass Communication, Louisiana State University, Baton Rouge, LA, USA

First Published:August2009

To cite this Article Cozma, Raluca and Maxwell Hamilton, John(2009)'Film Portrayals of Foreign Correspondents',Journalism Studies, 10:4,489 - 505

To link to this Article: DOI: $10.1080 / 14616700802622656$

URL: http://dx.doi.org/10.1080/14616700802622656

\section{PLEASE SCROLL DOWN FOR ARTICLE}

Full terms and conditions of use: http://www.informaworld.com/terms-and-conditions-of-access.pdf

This article may be used for research, teaching and private study purposes. Any substantial or systematic reproduction, re-distribution, re-selling, loan or sub-licensing, systematic supply or distribution in any form to anyone is expressly forbidden.

The publisher does not give any warranty express or implied or make any representation that the contents will be complete or accurate or up to date. The accuracy of any instructions, formulae and drug doses should be independently verified with primary sources. The publisher shall not be liable for any loss, actions, claims, proceedings, demand or costs or damages whatsoever or howsoever caused arising directly or indirectly in connection with or arising out of the use of this material. 


\title{
FILM PORTRAYALS OF FOREIGN CORRESPONDENTS
}

\section{A content analysis of movies before World War II and after Vietnam}

\author{
Raluca Cozma and John Maxwell Hamilton
}

This study combines content analysis and a close reading of movies to assess the portrayal of foreign correspondents in films during two periods: the golden age of foreign correspondence (the 1930s to World War II) and the years after the Vietnam War. The analysis revealed that movies generally depict foreign correspondents as heroes, but their status changes over time, and so do the circumstances in which they work. The differences during the two periods track changes for real foreign correspondents. In the golden age, silver screen correspondents were happy elites at ease with themselves even when stepping out of journalistic roles, unlike the latter period, when they were angst-ridden and questioned their responsibilities.

KEYWORDS film; foreign correspondence; media credibility; media history; movie portrayals

\section{Introduction}

It's not a fucking forties movie. You can't just get on a goddamn plane and make the whole world come out right. (Foreign correspondent Sydney Schanberg, as played by Sam Waterson in The Killing Fields, 1984)

Movies are commonly believed to both reflect and shape social perceptions, attitudes and behaviors (Berger, 1996; Welky, 2006; Zynda, 1979). This is particularly true when the audience has limited personal experience with the classes of people portrayed. Foreign correspondents, the most elite of all journalists, fall into this category. People get to know firefighters and doctors. They rarely meet a foreign correspondent. Zynda (1979) argues that Hollywood has a virtual monopoly on the public's image of the press, and Saltzman contends that journalists in the movies "have more power on the American consciousness than the real thing" (2002, p. 148).

This study investigates the image of foreign correspondents in American film and how this image has changed over time. What is foreign correspondents' relationship to society, editors, and family? How patriotic, confident or objective are they? One reason to ask these questions about the portrayal of foreign correspondents in American movies is the current concern about declining media credibility. Recent studies by the Pew Research Center and the American Society of Newspaper Editors, among others, found that the public views journalists as less accurate, too cynical, and "quite willing to hurt people just to publish a story" (American Society of Newspaper Editors Study, 1999). This analysis assesses whether foreign correspondents in the movies have undergone a parallel change that both projects and reinforces public concerns about the media. 
This research does that by examining the general patterns and frames associated with foreign correspondents in two periods using content and textual analysis. The first period covers the 1930s to the advent of World War II, often considered the golden age of foreign correspondence, and the second spans the 1980s and 1990s, after the Vietnam War, when journalism experienced declining credibility.

\section{Literature Review}

\section{The Good, the Bad, and the Ugly}

Scholars have created an aura around foreign correspondents, which emerge as an elite, specialized class apart and above regular reporters. Both journalists and scholars write glowingly about foreign correspondents. Moving with great freedom in politically sensitive regions of the globe, the foreign affairs correspondent is "a cosmopolitan among cosmopolitans, a man in gray flannel who ranks very high in the hierarchy of reporters" (Cohen, 1963). In his history of the American newspaper, Weisberger (1961, p. 161) wrote, "While the city beat might have its exciting side, the peak in reporting circles was reached when a writer could don a felt hat, riding boots, and a knapsack and swagger off to cover a war or a revolution." The standard history of foreign correspondents by John Hohenberg lionizes them and their work. Some correspondents have been captured, Hohenberg wrote, others have been wounded or killed in action, and most of them "preserved their independence and their integrity under pressure from governments, military censors, or facing the fire of a foe" (Hohenberg, 1995, p. xi). Much of this speaks to a time from the 1920s through World War II, which has been described as a golden age of foreign reporting (Hamilton, 2009; Heald, 1988, pp. xi, 152). In this period, memoirs, ${ }^{1}$ many of which were best sellers, brought foreign correspondents such as John Gunther to the status of celebrity. He and others showed up on the cover of Time magazine, ${ }^{2}$ were handsomely paid, awarded medals and honors, and married celebrities.

In recent years, the romantic image of the foreign correspondent has faded. One aspect of this is revelations of unethical behavior. In 2004, foreign correspondent Jack Kelley of USA Today was discovered to have fabricated substantial portions of several major stories, lifted nearly two dozen quotes or other material from competing publications without attribution, lied in speeches he gave for the newspaper, and conspired to mislead those investigating his work. The New York Times' Judith Miller's 2002 inaccurate front-page reporting on the existence of Weapons of Mass Destruction in Iraq prompted a public apology by the newspaper's editor. ${ }^{3}$ Stephen Glass' story of repeated journalistic fraud at The New Republic during the mid-1990s has been adapted for screen in Shattered Glass (2003), a movie that many journalism students watch in class when discussing media ethics.

Nor are correspondents today on the frontlines of popular wars. "Correspondence has somehow lost its glamour and its career appeal," British correspondent Alexander Cockburn (1974, p. 1) remarked. "Gone are the great days of a [William] Shirer or a [Negley] Farson, when European correspondents were cocks of the walk, face-to-face with Fascism, or watching bombs fall from the roof of the Savoy."

Recent studies focus on the negative aspects of foreign correspondence. Knightley (2004, pp. xi-xii), for instance, argues journalists are duped, sometimes willingly, into withholding information or providing errors in their reports during war. Herman and Chomsky (1988) challenge the "adversary press" image of journalists. News coverage of 
the Vietnam War was almost universally supportive of US policy until after large numbers of US troops had been engaged in the "intervention" in South Vietnam, heavy casualties had been taken, huge dollar sums had been spent, and elite protest had surfaced on grounds of threats to elite interests (Herman and Chomsky, 1988, p. 301). Herman and Chomsky argue foreign correspondence and the US media generally tailor their reporting to the money-dominated market for news. This results in highly selective messages that prevent the public from understanding the world in which they live and from exerting meaningful influence in the political process.

In his criticism of the shrinking hole for international news, former CBS correspondent Tom Fenton (2005) has lamented that foreign news after the Cold War has fallen into a dangerous decline. While the American involvement in Iraq has received considerable media attention, the number of correspondents generally has dropped, and with the meager resources left, news executives at home have shown little interest in covering important international stories that have no direct US connection. Americans were uninformed, unable to judge the accuracy of politically biased stories, and unprepared for the war on terror. The authoritative Tyndall Report (tyndallreport.com), which measures the coverage of international news by networks in three ways, offers a similarly gloomy picture of foreign news: a 65 percent drop in the use of the networks' overseas bureaus between 1989 and 2000; a 40 percent drop in stories devoted to US foreign policy; and a nearly 60 percent drop in stories about events abroad not tied to our foreign policy, which Thomas Kunkel (2001) calls "good old-fashioned foreign news."

Although foreign correspondents often appear in movies, no systematic study of foreign correspondents in film exists. Some notable researchers, however, have looked at the depiction of journalists in general and occasionally discussed the portrayal of foreign correspondents. Their findings, based on case studies or genre studies, show a mixed image of these journalists. Ehrlich (1997) studied about 150 Hollywood movies in which journalists are protagonists and in which their occupation is central to the plot. His exploratory approach, looking at the general themes and cultural tensions within the journalism movie genre, concludes that movies have portrayed journalists both as upstanding, heroic citizens and as scruffy outsiders and villains. Either way, Hollywood reproduced "myths in which the press is at the heart of things and always makes a difference" (Ehrlich, 2004, p. 1). In a recent study, Ehrlich (2006) has shown that heroic portrayals of journalists in general are rare. Far more common are depictions implying that journalists are social misfits who twist the truth into scandal and lack a conscience.

Zynda's (1979) study on the film portrayal of journalists concluded that movies often offer a critical and cynical view of journalism. The exception, the researcher noted, was with the two movies that included foreign correspondents-The Story of G. I. Joe (1945) and The Green Berets (1968). The journalists in these films are not portrayed as mercenary, but instead are interested in people. They are morally and physically courageous. This is in contrast with domestic journalists who show up in films as bitter and envious, with ignorant editors. Similarly, Cohen (1963) argues that the image of the reporter as a heavydrinking, hard-bitten cynic, interested only in sensational scoops does not apply to foreign correspondents.

Good (1989) makes the case that films tend to portray journalists as social outcasts, cynics and scandalmongers, and only sometimes as idealists and crusaders. He contends that this vision is distorted, melodramatic, superficial, and unfair. In his book, Outcasts: the image of journalists in contemporary film, Good dedicated one chapter to foreign 
correspondents. He looks at a limited number of war correspondents in films of the 1980s. The portrayal of correspondents, he argues, is negative. Foreign correspondents spread destruction, not understanding (1989, p. 65). Barris (1976), in Stop the Presses, has a chapter on the reporter overseas as well, but his approach is not analytical. He offers a historical catalog of the movies that focused on war correspondents, with details about the cast, writers and directors. His list stops with the 1960s and the Vietnam War.

Saltzman (2002, p. 146) argues that movie journalists "can lie, cheat, distort, bribe, betray, or violate any ethical code as long as the journalist exposes corruption, solves a murder, catches a thief, or saves an innocent." In other words, bad or unprofessional behavior is acceptable if in the end the journalist reports facts and truth in the public interest. The resulting portrayal is both celebratory and critical. In the movies of the 1930s, or what Ehrlich (2006, p. 509) calls the "screwball" era (which will also be under scrutiny in this study as the golden age of foreign reporting), glamour and happy endings redeem maverick, wisecracking, and outsider reporters. These films gloss over social rifts and economic misery during the Great Depression.

Taken together, these studies offer an incomplete and confused image of foreign correspondents. This research attempts to rectify that and in so doing limn a picture that other scholars can fill in with studies that go deeper or look at other periods of time.

\section{Research Questions}

This study explores the images of foreign correspondents projected on to movie theater screens and how that image changed from the golden age of foreign correspondence (1930s) to the more recent years (1980s and 1990s). The study is defined by the following research questions that examine the portrayal of foreign correspondents both at the movie and the character level:

$R Q$ 1: In what movie genres are foreign correspondents portrayed during the studied periods? Is there a difference between the golden-age and the contemporary movies?

This question aims to investigate how lightly or seriously films present foreign correspondents in the two periods.

$R Q$ 2: Are the foreign correspondent movies set against a backdrop of real events or based on true stories involving real journalists?

In other words, this section studies the extent to which the movies draw on reality, given the contention that Hollywood has a monopoly over the image of foreign correspondents, and hence a possible heightened cultivation effect when it comes to perceptions and attitudes toward this class of reporters. Cultivation researchers argue that film is the medium with the strongest visceral, intellectual and moral effects on society, followed by television (Berger, 1996; Nelmes, 2003).

Following from here and testing Lule's (2001, p. 15) argument that genre movies reproduce myths - "sacred, societal stories" that offer "exemplary models for human life" - the next questions look at the portrayal of foreign correspondents as professionals.

$R Q$ 3: What is the movies' overall message about journalism? Are the movies critical of journalism in any way or of foreign correspondents? 
This section looks specifically at the behavior of foreign correspondents - if they are heroic, for instance - and the problems they face, such as censorship or conflicts with others. We also assess if they are cynical and irreverent, kind and thoughtful, self-confident or self-important in the studied movies.

$R Q$ 4: Are foreign correspondents credible as reporters? Do they get involved in the stories they cover or do they stay detached?

These questions examine whether film correspondents during the two eras step out of their professional roles. The analysis looks at whether the movies focus on the correspondents' human side or the professional.

\section{Methods}

Content analysis - defined as "a research technique for the systematic, objective, and quantitative description of the manifest content in communication" (Kaid and Wadsworth, 1989) - was the main research method for this study. Open-ended questions left room for a close reading of the movies.

The researchers created a database of movies (see Appendix A) that depict foreign correspondents in their professional roles. As far as we know, this is the first attempt at compiling a more or less exhaustive database of such movies. We created it using secondary sources of information such as previous literature on journalists in the movies, extensive movie reviews in The Internet Movie Database archives, and the movie database of the Image of the Journalist in Popular Culture (IJPC) project. It is unrealistic to extract and unmanageable to code the entire population of such films, especially since in many of these movies foreign correspondents play only marginal roles. The researchers therefore decided to concentrate on two periods: the golden age of foreign correspondence, starting with the 1930s until World War II, and the 1980s and 1990s, following the end of the Vietnam War (see Appendix A). The 1930s is really the first period to have talking pictures and is a distinct journalistic era from the post-Vietnam era when news reporting changed in response to the war and later Watergate. Reporters became more suspicious and critical of official efforts to manage the news (Boylan, 1986; Fallows, 1997; Patterson, 1994). Westerstahl and Johansson (1994) argue that in the mass media, the most fundamental change in the twentieth century took place in the late 1960s, when a more active and critical journalism replaced the traditional, more reflective journalism.

By discarding the periods during World War II and Vietnam, we tried also to avoid the war propaganda that became intense in Hollywood at the time.

The next step was to record systematically the details of each relevant (i.e., journalistic) character in the selected movies. The content analysis examined two levels (units of analysis) - movie and character. The coding sheet included open-ended questions that allowed for additional notes on the movies' overall message about journalism and any relevant scenes and dialogues that would further enrich the quantitative analysis of the portrayals. The two researchers analyzed 32 movies ( 15 from the golden age and 17 from the contemporary period), which included a total of 48 characters playing roles of foreign correspondents. Each movie and each character received a separate coding sheet. The overall intercoder reliability calculated for 16 percent $(N=5)$ of the sample averaged 0.94 on Holsti's formula, and ranged from 0.81 to 1.00 for specific categories. The original sample contained 36 movies, but three were dropped after watching and analyzing them. 
James T. "Joker" Davis in Full Metal Jacket (1987) writes for Stars and Stripes but is portrayed merely as a soldier rather than a correspondent, and correspondents played a very small part in Four Frightened People (1934) and Exiled to Shanghai (1937). Also, the researchers found it impossible to locate a copy of the movie War Correspondent (1932) during the time of this analysis.

\section{Movie-level Analysis}

For the purposes of this study, we defined a movie as a full-length feature film featuring foreign correspondents in their professional roles. Movie analysis included an examination of the genre (action, mystery, drama etc.), year of release, name of director, name of producer, and period of time and event in which the story was set. It also captured whether the plot involved a real event or was based on a true story; the general, dominant atmosphere of the scenes (war or tension versus peace or calm, serious and sober versus joyful and high-spirited, dangerous versus safe); and the overall message about journalism (this was an open-ended question that looked at whether correspondents were portrayed in a dominantly positive or negative light and also noted details that might enhance the understanding of the movie's message).

\section{Character-level Analysis}

The study defined a character as a foreign correspondent who was a part of the narrative of the movie and central to the plot, although not necessarily the lead. Characters were coded for demographics (gender, race, age), role in the narrative (leading, supporting, episodic; hero, villain), and media affiliation. In order to assess the characters' relationships with others, the following variables were coded: conflicts (with competition, editors, military officials, local people or governments, etc.), censorship and other limits on their reporting, friendship with colleagues or other characters, heroic acts (seeking truth despite risks, saving someone, fighting in conflict, dying on the battlefield while trying to get a story out of enemy territory). With separate coding categories, the character-level analysis investigated whether the correspondents were confident or insecure and torn by angst, whether they became emotionally involved in the story or stayed detached, and whether they took a political side or stayed neutral. A series of categories coded the manner and demeanor of foreign correspondents, based on variables suggested by previous qualitative analysis of journalists in general, such as cynicism (character displays a belief that the boss/editor or his/her sources lack integrity, negative affect toward the people he/she deals with, and tendencies to disparaging and critical behaviors toward these entities that are consistent with these beliefs and affect) or self-confidence (the character is dominantly brash, self-assertive, without expressing doubts about his/her abilities or role). These categories were defined so as to be mutually exclusive.

One of the advantages of content analysis is the fact that quantification or measurement by coding teams permits reduction to numbers of large amounts of information or data that would be logistically impossible for close qualitative analysis. Properly operationalized and measured, such a process of reduction nonetheless retains meaningful distinctions among data while making generalizations possible (Riffe et al., 2005, p. 31). While quantitative analysis deals with manifest meanings of content (because they are easier to recognize and hence produce reliable results), qualitative analysis deals 
with latent, below-the-surface content, such as the context of a message, which is not as easy to observe, unless one is trained or happens to share the same meaning for certain symbols as the source of the message. In an effort to be both broad and deep, we combine elements of both types of analysis to show how the portrayal of foreign correspondence has evolved in response to broader changes in the social and cultural environment and how the movies illuminate the complexities and contradictions of reallife foreign correspondents.

\section{Results}

The first research question assessed the genres of movies in which foreign correspondents appeared. Each movie could belong to more than one genre. A majority (70 percent) of foreign correspondent movies were dramas, with no significant differences between the two periods. The next most favorite genres were war/combat (30 percent) and romance (30 percent). While there were significantly more comedies and romance movies in the 1930s, confirming Ehrlich's (2006) thesis about the "screwball" era of happyending romantic comedies, war and drama movies were fairly equally distributed between the two periods, as shown in the crosstabs in Table 1.

In terms of atmosphere, more movies (79 percent) were set against a background of war or tension than peace or calm. When comparing the two periods, however, significantly more contemporary movies (94 percent) involved war or tension than in the 1930s (63 percent). Similarly, contemporary movies had a serious, sober tone (88 percent) more often than did golden-age movies, the great majority of which (75 percent) were joyful and high-spirited. Although the 1980s and 1990s seemed more dangerous for foreign correspondents ( 88 percent, as compared to 67 percent), the difference did not reach statistical significance $(p=0.3)$.

The second research question investigated the extent to which real stories and foreign correspondents made their way into the movies. A sweeping majority ( 85 percent) of the movies took place amidst real overseas events (such as wars, revolutions,

TABLE 1

Movie-level differences between the two periods (\% of cases)

\begin{tabular}{|c|c|c|c|}
\hline & 1930s and 1940s & 1980s and 1990s & All movies \\
\hline \multicolumn{4}{|l|}{ Genre } \\
\hline Drama & 63 & 77 & 70 \\
\hline Comedy & $44^{* * *}$ & $0 * * *$ & 21 \\
\hline Romance & $44^{*}$ & $18^{*}$ & 30 \\
\hline War & 25 & 35 & 30 \\
\hline \multicolumn{4}{|l|}{ Atmosphere } \\
\hline Tension & $63^{* *}$ & $94^{* *}$ & 79 \\
\hline Serious, sober & $25^{* * *}$ & $88^{* * *}$ & 57 \\
\hline Dangerous & 69 & 88 & 79 \\
\hline Set in real event $†$ & 88 & 82 & 85 \\
\hline Based on true story $\dagger$ & $6^{* *}$ & $59 * *$ & 33 \\
\hline Some episodes are true stories & 19 & 18 & 18 \\
\hline Favorable depiction of journalists & 88 & 75 & 81 \\
\hline
\end{tabular}

Chi-square significant at ${ }^{*} p<0.1 ;{ }^{* *} p<0.05 ;{ }^{* * *} p<0.001$ levels.

$\dagger$ These categories are exclusive of each other, the others are not. 
occupations, anniversaries, end of a war or a revolution), with movies from the 1930s doing so slightly more (but not statistically significantly more) than the contemporary movies (88 percent compared to 82 percent, with $p=0.5$ ). Fifty-nine percent of the movies in the 1980s and 1990s, however, were based on true specific stories (biographies, smaller incidents) as compared to only 6 percent in the 1930s, suggesting that golden-age movies used historical events only as the larger context for the plot, without making use of a real character or a certain course of events that took place in history. Nonetheless, 19 percent of the movies in the golden age included some episodes of true stories. That is, they featured a few recognizable incidents in an otherwise fictional story.

At the character level (Table 2), the contemporary movies featured more characters inspired by real-life journalists (62 percent), while only 5 percent of the foreign correspondents in the 1930s were based on real journalists.

Partially answering the third research question, which investigated the overall message about foreign correspondence, Table 1 shows that 81 percent of all movies depicted journalists in an overall favorable light, without significant differences between the two periods. The coders had to weigh the positive and negative aspects of foreign correspondents and conclude whether the story chiefly focused on journalists' immorality, selfishness, or other negative personal qualities, or, on the contrary, highlighted their altruism and sense of duty to journalism and others.

While many golden-age movies portray foreign correspondents in a competitive environment, trying to double-cross each other in order to get a scoop, as the story progresses, many of the characters end up helping colleagues and others in need even at the expense of a scoop. These foreign correspondents come off as basically good people who want to get the story but have a broader commitment to fellow human beings. This is especially the case in 1930s "rival reporters" yarns, in which foreign correspondents are

TABLE 2

Character-level differences between the two periods (\% of cases)

\begin{tabular}{|c|c|c|c|}
\hline & 1930 s and $1940 s$ & 1980s and 1990s & All movies \\
\hline Real-life journalists & $5 * * *$ & $62^{* * *}$ & 35 \\
\hline \multicolumn{4}{|l|}{ Conflicts } \\
\hline With editor & $0^{*}$ & $15^{*}$ & 8 \\
\hline With other journalists & $46^{* *}$ & $15^{* *}$ & 29 \\
\hline With government & $23^{* *}$ & $58^{* *}$ & 42 \\
\hline Self-censorship & 18 & 19 & 19 \\
\hline Censorship & $18^{*}$ & $42 *$ & 31 \\
\hline \multicolumn{4}{|l|}{ Heroism } \\
\hline Seek truth despite risks & $59 *$ & $81 *$ & 71 \\
\hline Save someone & $59 *$ & $39 *$ & 48 \\
\hline Die trying to get story & $0^{*}$ & $15^{*}$ & 8 \\
\hline Cynical & 46 & 39 & 42 \\
\hline Irreverent & $55^{* *}$ & $23 * *$ & 38 \\
\hline Kind and thoughtful & 18 & 27 & 23 \\
\hline Self-important & $32 *$ & $15^{*}$ & 23 \\
\hline Become emotionally involved & 82 & 78 & 79 \\
\hline Take political side & $50 *$ & $28^{*}$ & 38 \\
\hline Torn by angst, insecure & $4^{*}$ & $19 *$ & 13 \\
\hline Speak foreign languages & $27^{* *}$ & $58^{* *}$ & 44 \\
\hline
\end{tabular}

Chi-square significant at ${ }^{*} p<0.1 ;{ }^{* *} p<0.05 ;{ }^{* *} p<0.001$ levels. 
deceitful, bent on success, and hedonistic, but in the end save the day (examples are movies like I'll Tell the World, 1934; Paris Interlude, 1934; Love on the Run, 1936; Everything Happens at Night, 1939; Comrade X, 1940; Confirm or Deny, 1941).

In the 1980s and 1990s, foreign correspondents also are heroes, but the focus is on censorship or conflicts with narrow-minded editors or government and military officials rather than other journalists. Indeed, the content analysis shows that foreign correspondents in the golden-age movies were significantly more likely (46 percent) than their contemporary counterparts ( 15 percent) to have conflicts with other journalists, and less likely to clash with editors ( 0 percent versus 15 percent) and military, law or government officials ( 23 percent versus 58 percent). The two groups experienced equal levels of selfcensorship (18 percent and 19 percent), but significantly more contemporary foreign correspondents (42 percent, as opposed to 18 percent) experienced censorship.

The code sheet included several categories that captured the characters' heroic acts. Seventy-one percent of all characters seek truth despite risks, with slightly more foreign correspondents doing so in the more recent movies (the difference approaches significance, at $p=0.09$ ). Forty-eight percent of all foreign correspondents save someone in the movie, with more correspondents being heroic in the golden age (the difference approaches significance, at $p=0.1$ ). Significantly more correspondents die trying to get the story in the contemporary movies ( 15 percent, as opposed to 0 percent), the finding suggesting once again that the golden-age movies preferred happy endings. The result also reflects a current concern about real-life foreign correspondents, who are working in ever more dangerous circumstances. The Iraq War is the deadliest conflict for the press in history, and the Committee to Protect Journalists and Reporters Without Borders release annual analyses that show that the numbers of killed journalists go up from one year to the other. A journalist safety survey found in 2007 that two journalists got killed every week in the last decade (International News Safety Institute, 2007).

The answers to the open-ended question about the overall message about journalism indicate that in the 1980s and 1990s correspondents chronicle, document and investigate to thwart political intrigue. They can be frayed, free-spirited, erratic, cynical and sometimes torn about their jobs, but they have a high sense of social responsibility (movies like Reds, 1981; The Killing Fields, 1984; Salvador, 1986; Double Exposure, 1989; The Infiltrator, 1995). In the golden age, the correspondents compete for scoops and have adventures. When it comes time to show their responsibility, they do so by becoming involved with the events or people they cover.

The crosstabs indicate the two groups of foreign correspondents are equally cynical and equally kind and thoughtful. The characters in the 1930s are slightly more selfimportant (32 percent versus 15 percent, which approached significance at $p=0.09$ ), and significantly more irreverent (55 percent versus 23 percent, $p=0.02$ ).

The fourth research question investigated the degree to which correspondents stepped out of their professional roles. Overall, 79 percent of foreign correspondents become emotionally involved in the story rather than staying detached. There are no significant differences between the two groups. Nineteen percent of contemporary foreign correspondents, however, are torn by angst, unsure or even critical about their role, as opposed to merely 4 percent of the golden-age characters. The findings suggest that while they always have a tendency to step out of their detached-journalist roles, foreign correspondents in the more recent years feel less comfortable doing it. Actually, the involvement in the story (or showing their human side) is precisely what redeems 
foreign correspondents in most of the 1930s movies. The finding supports Saltzman's (2002) theory that a journalist "can lie, cheat, distort, bribe, betray, or violate any ethical code as long as he exposes corruption, solves a murder, catches a thief, or saves an innocent." Foreign correspondents in the golden-age movies are also twice as likely as their contemporary counterparts to take political sides, such as supporting the revolutionaries/rebels or a side in a war (50 percent versus 28 percent).

$t$-Tests also brought support to our final hypothesis about the change in the correspondents' status over time. Indeed, in the golden age, foreign correspondents are significantly ( $p=0.02$ ) more likely to be portrayed as elites and celebrities $(M=1.6)$ than their contemporary counterparts $(M=1.2)$, who are portrayed more like outcasts or normal people doing a normal job. Foreign correspondents are also more formal and courteous in the 1930s and 1940s ( $M=1.8$ for formality and $M=0.73$ for courtesy) and more casual and even rude in the 1980s and 1990s $(M=0.3, p=0.01$ for informality and $M=0.27, p=0.001$ for rudeness).

Finally, the demographics statistics reflect the changes that foreign correspondence underwent over time. There are significantly more women in the contemporary movies (23 percent as opposed to 5 percent). Print journalists dominate movies in the 1930s (77 percent as opposed to 54 percent in the 1980s and 1990s). More contemporary correspondents are photojournalists ( 23 percent as opposed to none in the golden age) or broadcast journalists (19.5 percent as opposed to 4.5 percent). Twice as many foreign correspondents speak foreign languages in the recent movies (58 percent versus 27 percent, $p=0.03$ ). Not surprisingly, all foreign correspondents are white, and 96 percent appear to be between 30 and 45 years of age.

\section{Discussion}

Our findings indicate foreign correspondents are indeed a special class of journalists. We dropped the hero/villain variable from the analysis because none of the foreign correspondents depicted in the movies studied are villains, which in itself is telling about the image of foreign correspondents, especially since the result goes contrary to Ehrlich's (2006) findings about journalists in general. But the nature of heroism is different over the two periods. Those changes track the changes in the circumstances for real journalists.

While movie correspondents often dupe colleagues to get sensational scoops and are self-indulgent, most movies in this study offer a celebratory depiction of foreign correspondents. Journalists who initially appear to be self-interested or obnoxious have usually redeemed themselves by the time the credits roll at the end of the film. In Salvador (1986), foreign correspondent Richard Boyle, played by James Woods, confesses his idealistic credo: "I lost my hearing in this ear over here. Why do you think I did that? Fifteen dollars a photo from Pacific News Service? I did it because I believed in America. I believed that we stand for something. For Constitution. For human rights. Not just for a few people, but for everybody on this planet. Jack, you've got to think of the people first." As the entertainment periodical Variety had noted years before (1933), "The public's taste is educated to accept its newspaper characters as brittle and cynical, but ever staunch personalities."

Foreign correspondents do not spread destruction, as Good (1989) contends of journalists generally, but strive for understanding and truth. Many of them risk their lives in order to save someone or get a story. A few get killed while trying to do their job. But the 
correspondents operate in a far different context in the two eras. Correspondents in the golden-age films confront clear villains, whether they be spies, Nazis, or Mongol bandits. Their country may be slow to enter the war to help the rest of the world, but involvement is clearly justified and the reporter is pointing the way to that policy. Foreign correspondents in more recent movies confront evil actors, but often under circumstances that are ambiguous. Antagonists include citizens of their own country who have chosen to support the wrong side. While the military, diplomats, and other officials provide one obstacle to truth, the correspondents have to contend with narrow-minded editors.

Foreign correspondents' status in the movies has also changed over time. In the golden age they are portrayed as celebrities. In the recent movies, they are less glamorous, even seedy. Many are typically outcasts or normal middle-class people doing a normal job. This image accurately tracks the evolution of foreign correspondence over time. As a result of the ease of global travel and the emergence of new media, in which anyone with a computer can be a journalist, the foreign correspondent now is less elite (Hamilton and Jenner, 2004). Traditional foreign correspondents no longer have hegemony over foreign news.

Foreign correspondents make good material for movies in all ages. They are at home in war, revolutions, conflicts, and spy plots. But again, the use of foreign correspondents has changed from one period to the other. The golden-age movies occasionally make vague allusions to real correspondents like Paul Scott Mower (Clear All Wires!, 1933), Vincent Sheean (Foreign Correspondent, 1940), Lowell Thomas (I Cover the War, 1937), and Floyd Gibbons (Viva Villa!, 1934). But even these characters are fictional composites. Contemporary movies are more likely to tell real-life stories in which actual foreign correspondents face real challenges, often with unhappy consequences. The death of the editor in Under Fire (1983), for instance, has a real-life antecedent in the execution of ABC correspondent Bill Stewart in 1979, also in Nicaragua.

During the golden age of foreign correspondence, romance and comedy worked well for reporters of all kinds. The classic of the period was The Front Page, a play about metropolitan newspapering that became a highly popular film in 1931. The co-author of The Front Page was Ben Hecht, who had been a foreign correspondent for the esteemed Chicago Daily News foreign service and went on to help write screen plays for three films during the golden age: Viva Villa! (1934), Foreign Correspondent (1940), and Comrade X (1940). Many such films were irreverent about journalists, but also captured the sense of the fun and glamour that surrounded correspondents at the time. In sharp contrast, none of the movies in the second period attempted anything like comedy. Contemporary foreign correspondents, like real journalists, are depicted as less secure in their roles and less comfortable stepping out of them. "You just don't get involved," says the hero in Any Man's Death (1990). "It's the first rule in the cub reporter's manual. Do not get involved. Reporters are supposed to report and that's it."

In Foreign Correspondent (1940), which grew loosely out of Vincent Sheean's Personal History (1935), correspondent-hero Huntley Haverstock seamlessly moves from recorder of events to participant who helps stymie a Nazi plot. Haverstock, played by Joel McCrea, tells his story in one line: "My dear captain, when you've been shot down in a British plane by a German destroyer, 300 miles off the coast of England, latitude 45, and have been hanging on to a half-submerged wing for hours, waiting to drown, with half a dozen stricken human beings, you're liable to forget you're a newspaperman for a moment or two!" Director Alfred Hitchcock dedicated the film "to those intrepid ones who went across the 
seas to be the eyes and ears of America ... To those forthright ones who early saw the clouds of war while many of us at home were seeing rainbows ... To those clearheaded ones who now stand like recording angels among the dead and dying."

In contrast, Sydney Schanberg in The Killing Fields (1984) and Guy Hamilton, the journalist played by Mel Gibson in The Year of Living Dangerously (1982), uneasily wonder if they should be more involved or not. Likewise, modern correspondent movies are less likely to end on a happy note. At the end of Under Fire (1983), Russell Price (played by Nick Nolte) and his lover, both journalists, are left doubting the value of their profession. As a French spy tells them, they will not even know for 20 years if they have picked the right side in the Nicaraguan revolution they covered. After an American editor is murdered, a Sandinista woman poignantly observed that her cause might have been better advanced if they had "killed an American journalist 50 years ago." Equally troubling, the death of the editor is tied to Nolte's journalistically unethical decision to fake a picture to help the rebels. He is partly redeemed when he does just what a journalist is supposed to do: take real pictures - in this case, photos of his editor's murder.

\section{Conclusion}

Correspondents had good reason to be self-confident and independent during the 1930s. Technology had not yet reached the point at which correspondents were in permanent touch with the home office. On a long leash, correspondents typically wrote as they saw fit and moved about as they wished. Many made handsome incomes as freelancers. Also during this time, Americans were well liked and welcome around the world (Cole and Hamilton, 2008). A hotel concierge in Arise, My Love (1940) tells the foreign correspondent covering the war, "You are very lucky to be American. Europeans end a war just to start a new one." Many also believed that the threat of fascism required action on a global scale and accordingly viewed themselves as obliged to alert the public of what lay in the balance.

Not so today. Foreign correspondents working for major media outlets have less freedom to make decisions about where to go and what to cover. The United States is viewed as an imperial nation and often as an aggressor, which limits correspondents' access. As suggested above, they find themselves at odds with their own country's political policy and less admired by the public they are supposed to serve. In the end they are as defensive, as is Sydney Schanberg (played by Sam Waterston) in The Killing Fields (1984). Feeling guilty that his zeal to stay in Cambodia to cover the news may have cost the life of his Cambodian interpreter, friend and fellow journalist, Dith Pran (played by Haing Ngor), he says, "I did everything I could ... It's not a fucking forties movie. You can't just get on a goddamn plane and make the whole world come out right."

Movies of the 1930s often verged on popular propaganda, as it happened in Everything Happens at Night (1939), Espionage Agent (1939), Foreign Correspondent (1940), Arise, My Love (1940), and Confirm or Deny (1941). This would become even more pronounced, as Ehrlich (2006) notes, after Pearl Harbor, when Hollywood studios worked closely with the government to boost the war effort. The post-Vietnam pictures, on the other hand, reflected a growing emphasis on an adversarial relationship with officials and on conscientious professionalism within journalism to report facts.

This study looks at how movies, a cultural barometer, portray this class of journalists in the golden age compared to a contemporary period. The comparison helps us see the 
interplay of film and correspondence, mutually reinforcing each other. The cinema made the foreign correspondent, played by some of the era's greatest matinee idols, seem all the more romantic. But it is also of practical interest in the lesson it suggests for news media credibility.

Recent journalism critiques have questioned the determination of journalists to regain credibility by clinging to the artifices of detachment and "objectivity," with every fact or opinion highly sourced and little scope for reporters to freely employ their wisdom and experience - to write as Vincent Sheean did in 1938 after the German annexation of Austria:

I am unable to quote any sources or any authority for what I say, since nobody in Vienna is willing to be quoted, but investigations in the last ten days have given me one firm belief - that nothing will shake the power of national socialism here until it has completed its historic functions and has reached its natural and inevitable conclusion in general war.

More than 70 years later, journalist Mitchell Stephens agrees. "There is something to be said for being openly right or wrong," notes Stephens, "rather than hiding an assessment behind the carefully choreographed quotes of various named and unnamed sources" (Stephens, 2007, p. 38). As directors and their script writers have figured out, the most sympathetic correspondents were those who took a stand. And they were even more appealing when in the 1930s they did so without apology.

\section{NOTES}

1. Vincent Sheean's Personal History, published in 1935 and later adapted for the screen in Hitchcock's Foreign Correspondent, was the fourth best-selling non-fiction book that year, according to Publishers Weekly, and led the way for others in the same genre. The next year Negley Farson's The Way of the Transgressor, John Gunther's Inside Europe and Walter Duranty's I Write As I Please showed up on Publishers Weekly's list of the 10 most successful non-fiction books of the year.

2. Ernest Hemingway (1937 and 1944), Dorothy Thomson (1939), and Ernie Pyle (1944) were also Time cover stories.

3. For a sample of Miller's coverage of Iraq, visit http://nytimes.com/ref/international/ middleeast/20040526CRITIQUE.html. The New York Times' apology was printed in a editorial on May 26, 2004, "The Times and Iraq", available online at http://www.nytimes. com/2004/05/26/international/middleeast/26FTE_NOTE.html?ex $=1400990400 \& e n=94 \mathrm{cl}$ $7 \mathrm{fffad} 92 \mathrm{ca9} \& \mathrm{ei}=5007 \&$ partner $=$ USERLAND

\section{REFERENCES}

AMERICAN SOCIETY OF NEWSPAPER EDITORS (1999) "Examining Our Credibility: Perspectives of the Public and the Press", 4 August, http://www.asne.org/index.cfm?id=2632.

BARRIS, ALEX (1976) Stop the Presses! The newspaperman in American films, New York: A. S. Barnes and Company.

BERGER, ARTHUR (1996) Manufacturing Desire: media, popular culture, and everyday life, New Brunswick, NJ: Transaction Publishers. 
BOYLAN, JAMES (1986) "Declarations of Independence", Columbia Journalism Review 25(November/December), pp. 30-45.

COCKBURN, ALEXANDER (1974) "How to Earn Your Trench Coat", More, May, p. 1.

COHEN, BERNARD C. (1963) The Press and Foreign Policy, Princeton, NJ: Princeton University Press. COLE, JACI and HAMILTON, JOHN MAXWELL (2008) "The History of a Surviving Species: defining eras in the evolution of foreign correspondence", Journalism Studies 9, pp. 798-812.

EHRLICH, MATTHEW (1997) "Journalism in the Movies", Critical Studies in Mass Communication 14, pp. 267-81.

EHRLICH, MATTHEW (2004) Journalism in the Movies, Urbana and Chicago: University of Illinois Press.

EHRLICH, MATTHEW (2006) "Facts, Truth, and Bad Journalists in the Movies", Journalism 7, pp. 50119.

FALLOWS, JAMES (1997) Breaking the News, New York: Vintage Books.

FENTON, TOM (2005) Bad News: the decline of reporting, the business of news, and the danger to us all, New York: Regan Books.

GOOD, HOWARD (1989) Outcasts: the image of journalists in contemporary film, Metuchen, NJ: The Scarecrow Press.

HAMILTON, JOHN MAXWELL (2009) The Roving Eye: a history of American newsgathering abroad, Baton Rouge, LA: LSU Press.

HAMILTON, JOHN MAXWELL and JENNER, ERIC (2004) "Redefining Foreign Correspondence", Journalism: Theory, Practice and Criticism 5, pp. 301-21.

HEALD, MORRELL (1988) Transatlantic Vistas: American journalists in Europe, 1900-1940, Kent, OH: Kent State University Press.

HERMAN, EDWARD S. and CHOMSKY, NOAM (1988) Manufacturing Consent. The political economy of the mass media, New York: Pantheon Books.

HOHENBERG, JOHN (1995) Foreign Correspondence: the great reporters and their times, Syracuse, NY: Syracuse University Press.

INTERNATIONAL NEWS SAFETY INSTITUTE (2007) “Two Journalists Killed Every Week Over Last 10 Years", 3 June, http://www.newssafety.com/index.php?option =com_content\&view = article\&id =3805:qtwo-journalists-killed-every-week-over-last-10-yearsq-says-journalistsafety-survey\&catid $=535$ :articles\&ltemid $=100504$, accessed 23 October 2008.

KAID, LYNDA LEE and WADSWORTH, ANNE JOHNSTON (1989) "Content Analysis", in: Phillip Emmert and Larry L. Barker (Eds), Measurement of Communication Behavior, New York: Longman.

KNIGHTLEY, PHILLIP (2004) The First Casualty. The war correspondent as hero and myth-maker from the Crimea to Iraq, Baltimore, MD and London: The Johns Hopkins University Press.

KUNKEL, THOMAS (2001) “The View from Down Under: international news isn't necessarily foreign", American Journalism Review, September, p. 4.

LULE, JACK (2001) Daily News, Eternal Stories: the mythological role of journalism, New York: Guilford.

NELMES, JILL (2003) An Introduction to Film Studies, London and New York: Routledge. PATTERSON, THOMAS (1994) Out of Order, New York: Vintage Books.

RIFFE, DANIEL, LACY, STEPHEN and FICO, FREDERICK G. (2005) Analyzing Media Messages. Using quantitative content analysis in research, Mahwah, NJ: Lawrence Erlbaum.

SALTZMAN, JOE (2002) Frank Capra and the Image of the Journalist in American Film, Los Angeles: Image of the Journalist in Popular Culture.

SHEEAN, VINCENT (1935) Personal History, Garden City, NY: Doubleday, Doran \& Co. SHEEAN, VINCENT (1938) New York Herald Tribune, 5 July, p. 1. 
STEPHENS, MITCHELL (2007) "Beyond News", Columbia Journalism Review 38(January/February), pp. 34- 45.

VARIETY (1933) Variety Film Reviews, New York: Garland Publishing, 7 March.

WEISBERGER, BERNARD A. (1961) The American Newspaper Man, Chicago: University of Chicago Press.

WELKY, DAVID (2006) "Global Hollywood vs. National Pride: the battle to film 'The Forty Days of Musa Dagh"', Film Quarterly 59(3), pp. 35-43.

WESTERSTAHL, JÖRGEN and JOHANSSON, FOLKE (1994) "Foreign News: news values and ideologies", European Journal of Communication 9(1), pp. 71-89.

ZYNDA, THOMAS H. (1979) "The Hollywood Version: movie portrayals of the press", Journalism History 6(2), pp. 16-25.

\section{Appendix A}

Database of Movies Portraying Foreign Correspondents

Movies analyzed in this study are indicated by an asterisk.

War Correspondent (1932)

Clear All Wires! (1934)*

Four Frightened People (1934)

I'll Tell the World (1934)*

Paris Interlude (1934)*

Viva Villa! (1934)*

Next Time We Love (1936)*

Love on the Run (1936)*

Exiled to Shanghai (1937)*

Fly Away Baby (1937)

I Cover the War (1937)*

Last Train from Madrid (1937)*

Barricade (1939)*

Espionage Agent (1939)*

Everything Happens at Night (1939)*

Stanley and Livingstone (1939)*

A Dispatch from Reuter's (1940)

Arise, My Love (1940)*

Comrade X (1940)*

Foreign Correspondent (1940)*

Affectionately Yours (1941)

Confirm or Deny (1941)*

A Yank in Libya (1942)

Berlin Correspondent (1942)

China Girl (1942)

Cairo (1942)

Dangerous Moonlight (1942)

Once Upon a Honeymoon (1942)

Somewhere I'll Find You (1942) 
The Day Will Dawn (1942)

Behind the Rising Sun (1943)

Guadalcanal Diary (1943)

The Desert Song (1943)

The Lady Has Plans (1943)

They Got Me Covered (1943)

Passage to Marseille (1944)

Blood on the Sun (1945)

The Story of G. I. Joe (1945)

Objective, Burma! (1945)

Sing Your Way Home (1945)

Lover Come Back (1946)

Malaya (1949)

Here Comes the Groom (1951)

Assignment: Paris (1952)

Little Boy Lost (1953)

Never Let Me Go (1953)

Sky Commando (1953)

Love Is a Many-splendored Thing (1955)

Tiger by the Tail (1955)

Don't Go Near the Water (1957)

Another Time, Another Place (1958)

Cuban Rebel Girls (1959)

The Angry Hills (1959)

Yesterday's Enemy (1959)

Lawrence of Arabia (1962)

The Bedford Incident (1965)

Anzio (1968)

The Green Berets (1968)

The Shoes of the Fisherman (1968)

Young Winston (1972)

Reds (1981)*

The Year of Living Dangerously (1982)*

Last Plane Out (1983)*

Love Is Forever (1983)*

Under Fire (1983)*

The Killing Fields (1984)*

Eleni (1985)*

Salvador (1986)*

Full Metal Jacket (1987)

A World Apart (1988)

Margaret Bourke-White (1989)*

Old Gringo (1989)*

One Man Out (1989)*

The Nightmare Years (1989)*

Any Man's Death (1990)*

Cover Up (1991)* 
The Infiltrator (1995)*

Three Kings (1999)*

The Quiet American (2002)

And Starring Pancho Villa as Himself (2003)

Live from Baghdad (2003)

Raluca Cozma (author to whom correspondence should be addressed), Manship School of Mass Communication, Louisiana State University, 211 Journalism Building, Baton Rouge, LA 70803, USA. E-mail: rcozma1@Isu.edu

John Maxwell Hamilton, Manship School of Mass Communication, Louisiana State University, 213 Journalism Building, Baton Rouge, LA 70803, USA. E-mail: jhamilt@Isu.edu 